\title{
Protective Effects of $\omega-3$ fatty acids and/ or Nano- selenium on Cisplatin and lonizing radiation induced liver toxicity in rats
}

\author{
Hanan A Fahmy', Afrag Sh Abd El Azim², Ola A Gharib1 \\ 'Drug Radiation Research Department, National Center of Radiation Research and Technology, Atomic Energy Authority, Egypt. \\ ${ }^{2}$ Radiation Biology Department, National Center of Radiation Research and Technology, Atomic Energy Authority, Egypt.
}

\begin{abstract}
Cisplatin (CP) and/ or radiation exposures cause oxidative stress, which induced liver toxicity. The present study was undertaken to explore if fish oil (FO) and /or selenium nano particles (SeNPs) can minimize CP-induced hepatotoxicity and other side effects. Rats were either treated with SeNPs $(0.5 \mathrm{mg} / \mathrm{kg})$ and /or FO $(2 \mathrm{mg} / \mathrm{Kg})$ for 12 days before treatment with $\mathrm{CP}(10 \mathrm{mg} / \mathrm{Kg})$ and/ or exposure to $\gamma$-rays $(0.7 \mathrm{~Gy})$. The results of the present study revealed that rats treated with $\mathrm{CP}$ and /or $\gamma$-radiation showed an increase in the level of IL6, renin and the expression of angiotensinogen, xanthine oxidase (XO) and NF- $\mathrm{KB}$ protein along with a decrease in (Nrf2) protein expression as well as, the activity of antioxidant enzymes. Fish oil and /or selenium nanoparticles (SeNPs) treatment prior to $\mathrm{CP}$ and/ or radiation exposure normalized these parameters. Our findings suggest that FO together with SeNPs could be used as protective supplements against toxicity associated with ionizing radiation and CP due to its antioxidant, anti-inflammatory and anti-apoptotic properties.
\end{abstract}

Key words: Ionizing radiation, Cisplatin, Omega 3, Selenium nano particles, Nrf2, NF-кB.

\section{INTRODUCTION}

Radiotherapy acts via the initiation of double strand breaks to DNA in order to induce elimination of cancerous cells via apoptosis. ${ }^{1} \mathrm{CP}$ is regarded as a major drug against a broad spectrum of leukemia and malignant tumor. CP cytotoxicity includes production of ROS, cell cycle arrest in the G2-phase and then induces programmed cell death. ${ }^{2}$ The efficiency of using radiotherapy as well as chemotherapy for cancer treatment is restricted due to side toxic effects.

Nuclear transcription factor-kB $(\mathrm{NF}-x \mathrm{~B})$ is an important transcription factor which play role in the regulation of innate immunity, inflammatory responses, cellular growth, and apoptosis. In addition, this transcription factor is persistently active in a number of disease states, including cancer, arthritis and chronic inflammation. ${ }^{3}$ Previous reports showed that ionizing radiations and cytotoxic agents, including $\mathrm{CP}$ activate $\mathrm{NF}-\varkappa \mathrm{B}$ via protein kinases and reactive oxygen species (ROS) that are produced during irradiation and cytotoxic drugs. ${ }^{4,5}$

Nuclear factor erythroid-derived 2 (Nrf2) is a key regulator of the antioxidant responsive element (ARE) - mediated gene expression. ${ }^{6}$ Previous studies reported interplay between Nrf2 and NF- $x \mathrm{~B}$ signaling pathways. Compounds targeting the Nrf2 pathway suppress the abnormal inflammatory responses controlled by NF- $x$ B pathway. ${ }^{7}$ The aim of combining chemo and radio-therapy is to reinforce the efficiency of radiation by inhibition of DNA repair of cancer cell as
Submission Date : 24-06-2016 Revision Date : 31-08-2016 Accepted Date : :14-09-2016

DOI: 10.5530/ijper.50.4.17 Correspondence: Hanan fahmy*,

Ph.no: 22-02-22668185 E-mail: fahmy.hanan@ yahoo.com

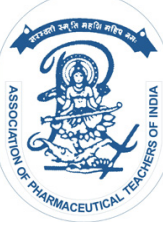

www.ijper.org 
well as, activation of apoptotic pathway. ${ }^{8}$ Consequently, pharmacological inhibition of $\mathrm{NF}-x \mathrm{~B}$ would be an approach to potentiate cancer therapy.

Previous study suggests that using chemo-preventive agents together with chemotherapy can augment the efficacy of chemotherapeutic agents and lower their toxicity to normal tissues. ${ }^{9}$ The essential omega fatty acids ( $\omega$ FA) in the human diet are $\omega-3$ and $\omega-6$ FA. ${ }^{10}$ FO contains two omega-3 fatty acids named docosahexaenoic acid (DHA) and eicosapentaenoic acid (EPA). Omega-3 fatty acids (Omega-3 FAs) are considered as strong antioxidants; possess anti-inflammatory properties via inhibiting the pro-inflammatory transcription factor $(\mathrm{NF}-x \mathrm{~B})$, and induction of an "anti-inflammatory" eicosanoid profile..$^{11,12}$

Among the natural product Se element is attracting the attention due to its chemo preventive anti-cancer, antimetastasis capacity, inhibition of angiogenesis, antioxidant properties, and promotion of vascular maturation and enhancement of drug delivery. ${ }^{13}$ Nano technology holds a guarantee in medicine since materials at the nanometer dimension display novel properties different from those of bulk material, such as increase bioavailability of drugs, development of new medicines which are more safe. ${ }^{14}$ The introduction of nano-size elemental selenium showed an efficacy in increasing antioxidant GPx activity while exhibiting lower toxicity. ${ }^{15}$ These SeNPs also show high biological activity and more absorptive ability due to the interaction between the nano-particles, $-\mathrm{NH}_{2}, \mathrm{C}=\mathrm{O},{ }^{-} \mathrm{COO}$ and $-\mathrm{C}-\mathrm{N}-$ groups of proteins. ${ }^{16}$ Biological activities of selenium and its nano-forms revealed that hollow spherical nanoparticles of selenium have potent antioxidant properties with reduced risk of selenium toxicity. ${ }^{17}$

The aim of this study is to enhance the effectiveness of $\mathrm{CP}$ in cancer treatment by exposing the animals to a single dose of $\gamma$-radiation ( $0.7 \mathrm{~Gy}$ ), and to what extent FO and SeNPs antioxidants could be used as a potential treatment for $\mathrm{CP}$ and radiation induced hepatotoxicity. To address our hypothesis pro-inflammatory status (renin, angiotensinogen and IL6), antioxidant enzymes (PON-1, GPx), and protein expression profile (NF- $x \mathrm{~B}$ and Nrf2 protein) were examined.

\section{MATERIALS AND METHODS Chemicals}

$\mathrm{CP}$ used in this experiment was purchased from Pfizer Co. Egypt, and was used at the dose of $10 \mathrm{mg} / \mathrm{kg}$ body weight i.p. ${ }^{18}$ FO was obtained from the Arab Co. for Gelatin and Pharmaceutical Products, and was at the dose of $2 \mathrm{ml} / \mathrm{kg}$ body weight. ${ }^{19} \mathrm{SeNPs}(49.6 \mathrm{~nm} \pm 8.7 \mathrm{SD})$ particle size was prepared according to the method described previously. ${ }^{20}$

\section{Experimental animals}

This study was approved to be carried out by the Committee of Scientific Ethics at of Faculty of pharmacy, Al-Azhar University, Egypt, following the guidelines of for animal use. Forty two male albino rats weighing 200-250 $\mathrm{g}$ were used in this study. They were attained from Nile Pharmaceutical Co, Cairo, Egypt. They were kept under comfortable environmental conditions. They were maintained in stainless steel cages in a well-ventilated animal house at temperature of about $22^{\circ} \mathrm{C} \pm 5^{\circ} \mathrm{C}$ under a 12:12-hour light-dark cycle for two weeks for adaptation. The rats were maintained on a standard diet and provided water ad libitum.

\section{Experimental design}

It was intended to use a radiation dose level of $0.7 \mathrm{~Gy}$ to enhance the synergistic action of both chemo-radiotherapy; in mean time the dose level was not too high to avoid radiation risk hazards. The applied dose of CP, FO and SeNPs were chosen according the information cited in literature. ${ }^{18-20}$

Rats were randomly divided into seven equal groups (6 rats each). Group 1 (Control group) control untreated group. Group 2 (CP group) rats were given a single dose of CP (10 mg/ kg body weight i.p). Group 3 (IRR group) rats were exposed to a single dose of $0.7 \mathrm{~Gy}$ $\gamma$-rays. Group 4 (CP + IRR group) rats were given CP i.p. and then exposed to a single dose of $0.7 \mathrm{~Gy} \gamma$-rays after $24 \mathrm{~h}$ post CP injection. Group $5(\mathrm{FO}+\mathrm{CP}+$ IRR group) rats were administered FO $(2 \mathrm{ml} / \mathrm{kg}$ body weight) orally and daily for 12 consecutive days and then injected with CP i.p. after half an hour of the last dose of FO. Twenty-four hours after the CP injection, the animals were irradiated with 0.7 Gy $\gamma$-rays. Group 6 (SeNPs + CP + IRR group) rats were given SeNPs ( $0.5 \mathrm{mg} / \mathrm{kg}$ body weight) orally and daily for 12 consecutive days and then injected with CP i.p. after half an hour of last dose of SeNPs. After the $24 \mathrm{~h}$ of CP injection; rats were exposed to $0.7 \mathrm{~Gy}$ of $\gamma$-rays. Group 7 (FO+ SeNPs + CP + IRR group) rats were given FO concurrently with SeNPs (daily) for 12 consecutive days, after half an hour of the last dose of both FO and SeNPs, rats were injected with a single dose of CP i.p. Twenty-four hours later rats were exposed to $0.7 \mathrm{~Gy}$ of $\gamma$-rays. Animals were decapitated and the blood was collected for biochemical analysis $24 \mathrm{~h}$ post radiation exposure. Serum was obtained and stored at $-20^{\circ} \mathrm{C}$ until analysis. Liver was excised, homogenized in ice-cold saline and used for several biochemical analyses. 


\section{Irradiation of experimental animals}

Rats were whole body $\gamma$-irradiated with a single dose of $0.7 \mathrm{~Gy}$, using cesium 137 irradiation units at the National Center of Radiation Research and Technology (NCRRT) with a dose rate of $0.71993 \mathrm{rad} / \mathrm{sec}$. Cesium cell was standardized by alanine dosimetry relative to a primary standard. Correction were made daily for humidity, barometric pressure and temperature.

\section{Biochemical studies}

The following parameters were measured in the serum of the seven tested rat groups, according to the instructions of their referred methods. Serum renin measured by Elisa kit renin (My Biosource USA). Serum IL6 was determined by R\&D system USA according to manufacturer's instruction, while PON-1 activity was assayed in liver tissue according to the method of Rodrigo et al. ${ }^{21}$ GPx activity was measured conferring to the method describe by Rotruck et al..$^{22}$

\section{Real-time quantitative polymerase chain reaction (PCR)}

Liver xanthine oxidase and angiotensinogen gene expression were measured by means of real time PCR (RT- PCR). Total RNA was sequestered from liver tissue homogenates using RNeasy Purification Reagent (Qiagen, Valencia, CA) conferring to the manufacturer instruction. The concentration of RNA was measured using UV spectrophotometer. For cDNA synthesis, five-microgram RNA was reverse transcribed using oligonucleotide (dT) 18 primer [final concentration, $0.2 \mathrm{mM}$ and was denatured at $70^{\circ} \mathrm{C}$ for $2 \mathrm{~min}$. Denatured RNA was kept on ice and reverse transcription mixture including $50 \mathrm{mM}$ $\mathrm{KCl}, 50 \mathrm{mM}$ Tris $\mathrm{HCl}(\mathrm{pH} 8.3), 0.5 \mathrm{mM}$ of deoxyribonucleotide triphosphate (dNTP), $3 \mathrm{mM} \mathrm{MgCl}, 1 \mathrm{U} / \mathrm{ml}$ RNase inhibitor, and 200 units of Moloney murine leukemia virus reverse transcriptase. The reaction tube was placed at $42^{\circ} \mathrm{C}$ for $1 \mathrm{~h}$, followed by heating to $92^{\circ} \mathrm{C}$ to stop the reaction. For real-time quantitative PCR, $5 \mu \mathrm{L}$ of first-strand cDNA was used in a total volume of $25 \mu \mathrm{L}$, containing $12.5 \mu \mathrm{L} 2$ x SYBR Green PCR Master Mix [Applied Biosystems, Foster City, CA, USA and $200 \mathrm{ng}$ of each prime. PCR reactions consisting of $95^{\circ} \mathrm{C}$ for $10 \mathrm{~min}(1 \mathrm{cycle}), 94^{\circ} \mathrm{C}$ for $15 \mathrm{~s}$, and $60^{\circ} \mathrm{C}$ for $1 \mathrm{~min}$ (40 cycles), were achieved on step one plus Real Time PCR system (Applied Biosystems). Data were evaluated with the ABI Prism 7500 sequence detection system software and quantified by the $\mathrm{v} 1 \cdot 7$ Sequence Detection Software from PE Biosystems (Foster City, CA). The housekeeping gene $\beta$ - Actin was used as a reference gene for standardization. Primers used for rat genes were as following: XO:
F: 5' CGCAGAATACTGGATGAGCGAGGT 3', R: 5' GCCGGTGGGTTTCTTCTTCTTGAA 3'; Angiotensinogen: F: 5' GAG GGG GTC AGC ACG GAC AGC ACC 3', R: 5' TCC TGT GGC ATC CAT GAA ACT ACA T'TC 3'; $\beta$ - Actin: F: 5' GGGAAATCGTGCGTGACAT'T 3', R: 5'- GCGGCAGTGGCCATCTC-3'. Relative expression of studied genes was calculated by means of the comparative threshold cycle method. All values were normalized to the $\beta$ - Actin genes. ${ }^{23}$

\section{Western blotting}

$\mathrm{NF}-x \mathrm{~B}$ and Nrf2 protein expression were detected using Western blot analysis in liver tissue of the seven tested groups. Total protein was extracted from tissue using a protein extraction kit. Total protein levels were determined by Bradford method. Equal amounts of the protein samples were separated by sodium dodecyl sulfate-polyacrylamide gel electrophoresis (SDS-PAGE) and electro-transferred to PVDF membranes. The membranes were incubated overnight with anti-beta actin antibody (1:1000 dilution; thermo scientific), NF-KB and Nrf2 antibody (1:2000 dilution; Abcam, Cambridge, MA, United States) incubated with a mouse anti-rabbit secondary monoclonal antibody conjugated to horseradish peroxidase at room temperature for $2 \mathrm{~h}$. The membranes were washed four times with $10 \mathrm{mM}$ Tris-Cl, pH 7.5, $100 \mathrm{mM} \mathrm{NaCl}$, and $0.1 \%$ Tween 20 at room temperature. Chemiluminescence detection was performed with the BioRad detection kit according to the manufacturer's protocols. The amount of NF- $x \mathrm{~B}$ and Nrf2 protein was quantified by densitometric analysis using Bio-Rad software (Bio RAD., USA). Results were expressed as arbitrary units after normalization for $\beta$-actin protein expression.

\section{Statistical Analysis}

To evaluate the significant level of influence caused by the combination effects of FO and SeNPs, in CP irradiated rats, one way analysis of variances (ANOVA) followed by Tukey's multiple comparison test was used. Statistics are representative of 6 independent experiments carried out in triplicate. Statistical analysis was done by using Graph-Pad software prism version 5, San Diego, CA, USA. Differences were considered statistically significant at $\mathrm{P}<0.05$.

\section{RESULTS}

\section{Assessment of antioxidant enzymes in liver}

Table 1 illustrates the effect of cisplatin and/ or $0.7 \mathrm{~Gy}$ $\gamma$-radiation exposures on liver GPx and PON-1 activities. $\mathrm{CP}$ and/ or radiation exposure (groups 2, 3 and 4) resulted in a highly significant decline in both liver GPx 
and PON-1activity as compared to control rats (group 1). The decrease in GPx and PON-1activity was more pronounced in group subjected to double treatment of $\mathrm{CP}$ and $\gamma$-rays (group 4). Moreover, administration of FO and/ or SeNPs (groups 5, 6 and 7) to rats caused a moderate restoration especially in $(\mathrm{FO}+\mathrm{SeNPs}$ $+\mathrm{CP}+\mathrm{IRR}$ ) group; since both treatments were affected clearly on the level of the previous parameters (Table 1).

\section{Assessment of pro-inflammatory markers in serum}

Results summarized in Table 2 showed the effect of CP and/ or $0.7 \mathrm{~Gy} \gamma$-radiation exposures on serum renin and IL6. CP and/ or $\gamma$-irradiation resulted in a sharp increase in both serum renin and IL6 compared to control rats. The increase was insignificant between $\mathrm{CP}$ and IRR group in both parameters, while a combined treatment as in CP + IRR group caused a highly significant increase in serum renin and IL6 levels as compared to group control, CP and IRR individually. Administration of FO and/ or SeNPs (groups 5, 6 and 7) caused a moderate amelioration which became more obvious in group of rats treated with combined treatment of $\mathrm{FO}$ and SeNPs as compared to the (CP+IRR) groups but still showed significant increase as compared to normal control level (Table 2).

\section{Assessment of gene expression in liver}

Real-time PCR showed that XO and angiotensinogen were over activated by the treatment of rats by CP, radiation and their combination (groups 2, 3 and 4), which became significantly changed compared to normal control group (Table 3). The present results revealed a highly significant decrease in the relative expression level of liver angiotensinogen in group $5(\mathrm{FO}+\mathrm{CP}+$ IRR) as well as liver $\mathrm{XO}$ and angiotensinogen in group 7 (FO + SeNPs + CP + IRR) comparing with treated control groups (2- 4) individually and showed a moderate restoration as compared to the normal control levels.

\section{Assessment of protein expression in liver}

Treatment of rats with $\mathrm{CP}$ and/ or radiation exposure (groups 2, 3 and 4) revealed a significant increase in liver $\mathrm{NF}-\boldsymbol{x B}$ protein expression accompanied by decrease in Nrf2 protein expression as compared to the control group. On the other hand, rats pretreated with $\mathrm{FO}$ and SeNPs suppresses the expression of NF- $x \mathrm{~B}$ induced by $\mathrm{CP}$ and radiation along with an increase in the expression Nrf2 groups 5, 6 and 7 (Figure 1).

\section{DISCUSSION}

In the current study, the molecular mechanisms underlying the possible liver radio protective effect of FO and SeNPs have been evaluated in an experimental model of $\mathrm{CP}$ and radiation-induced hepatotoxicity.

In the present study, administration of $\mathrm{CP}$ and/or radiation exposure of rats caused a significant decrease in the activity of GPx, PON-1 with the increase in the expression of $\mathrm{XO}$ as compared to control values. Previous investigators accounted comparable data. They noted a decrease in the level of GPX and PON-1 with an increase in the level of xanthine oxidase after $\mathrm{CP}^{24}$ treatment as well as, exposure to $\gamma$-rays. ${ }^{25}$ the decreased activity of GPx resulted in the decreased ability of the liver to scavenge toxic $\mathrm{H}_{2} \mathrm{O}_{2}$ and lipid peroxides. CP led to an increase in $\mathrm{XO}$ activity, possibly through the conversion reaction of xanthine dehydrogenase to $\mathrm{XO} .{ }^{26}$ Increased activity of $\mathrm{XO}$ enzyme is a vital risk factor for the oxidant burden in the liver tissue as it is the main enzyme producing toxic superoxide radical in vivo. ${ }^{27}$ Thus, declined antioxidant status partially explains the mechanism of hepatootoxicity induced by CP and /or $\gamma$-irradiation.

Besides, the oxidative stress analysis, the current study showed that administration of CP and/ or radiation exposure of rats caused a significant increase in the serum IL6 level, renin activity as well as, liver angiotensinogen gene expression and NF- $x \mathrm{~B}$ protein expression, which were accompanied by a decrease in the expression of $\mathrm{Nrf2}$ protein. Alteration in all tested parameters was augmented in rats treated with $\mathrm{CP}$ and $\gamma$-rays; indicating that irradiation intensify the toxic effect of CP. These results indicate that the mechanism of $\mathrm{CP}$ and /or irradiation-induced liver damage may be mediated by $\mathrm{NF}-x \mathrm{~B}$ and angiotensinogen activation as well as, the increases in the level of IL-6 inflammatory cytokines. The pro-inflammatory cytokine, including IL-6 and reactive oxygen species (ROS), induced by the administration of $\mathrm{CP}$ and ionizing radiation, are the most common factors that induce NF- $x \mathrm{~B}$ activation. ${ }^{28}$ Ionizing radiations and cytotoxic agents (CP) activate $\mathrm{NF}-x \mathrm{~B}$ via the protein kinases ATM or DNA-PK. ATM is a nuclear serine kinase that upon sensing DNA damage activates several signaling pathways to regulate cell cycle, stress and DNA repair. ${ }^{29,30}$ Angiotensinogen is an essential member in the renin-angiotensin system (RAS). ${ }^{31}$ Interestingly, angiotensinogen functions as a reservoir for angiotensin I (AngI), which is cleaved from the $\mathrm{N}$ terminal by the enzyme renin and then converted into AngII, which causes liver damage ${ }^{32}$ therefore, its level is a good indicator of liver damage. AngII is involved 

Table 1: Changes in liver GPX (U/g tissue) and PON-1(nmol/min./mg tissue) activities in rats treated
with CP and / or y-radiation ( 0.7 Gy) and the ameliorative role of FO and/ or SeNPs treatment

\begin{tabular}{|c|c|c|c|c|c|c|c|}
\hline \multirow[b]{3}{*}{ Parameter } & \multicolumn{7}{|c|}{ Experimental groups } \\
\hline & Group 1 & Group 2 & Group 3 & Group 4 & Group 5 & Group 6 & Group 7 \\
\hline & Control & $\mathrm{CP}$ & IRR & CP+ IRR & $\begin{array}{l}\mathrm{FO}+\mathrm{CP}+ \\
\text { IRR }\end{array}$ & $\begin{array}{c}\text { SeNPs+ CP } \\
+ \text { IRR }\end{array}$ & $\begin{array}{c}\text { FO+ } \\
\text { SeNPs+ CP } \\
+ \text { IRR }\end{array}$ \\
\hline GPx & $\begin{array}{c}52.29 \\
\pm 10.70\end{array}$ & $\begin{array}{c}33.88 \\
\pm 6.293^{*}\end{array}$ & $\begin{array}{c}38.41 \\
\pm 6.402\end{array}$ & $\begin{array}{c}36.12 \\
\pm 2.533^{*}\end{array}$ & $\begin{array}{c}45.10 \\
\pm 3.119\end{array}$ & $\begin{array}{c}47.85 \\
\pm 2.95^{*}\end{array}$ & $\begin{array}{c}44.82 \\
\pm 6.766\end{array}$ \\
\hline PON-1 & $\begin{array}{c}240.2 \\
\pm 37.82\end{array}$ & $\begin{array}{c}161.3 \\
\pm 18.44^{*}\end{array}$ & $\begin{array}{c}160.7 \\
\pm 9.522^{*}\end{array}$ & $\begin{array}{c}175.0 \\
\pm 28.26\end{array}$ & $\begin{array}{c}183.3 \\
\pm 19.74^{*}\end{array}$ & $\begin{array}{c}186.7 \\
\pm 24.26\end{array}$ & $\begin{array}{c}206.7 \\
\pm 9.761^{*}\end{array}$ \\
\hline
\end{tabular}

Results are expressed as means $\pm S D(n=6)$. * significant difference from control group, $\neq$ significant difference from $(C P+I R R)$ treated group at $P<0.05$.

\begin{tabular}{|c|c|c|c|c|c|c|c|}
\hline \multirow{3}{*}{ Parameter } & \multicolumn{7}{|c|}{ Experimental groups } \\
\hline & Group 1 & Group 2 & Group 3 & Group 4 & Group 5 & Group 6 & Group 7 \\
\hline & Control & $\mathrm{CP}$ & IRR & CP+IRR & $F O+C P+I R R$ & $\begin{array}{c}\text { SeNPs+ CP+ } \\
\text { IRR }\end{array}$ & $\begin{array}{c}\text { FO+ SeNPs+ } \\
\text { CP + IRR }\end{array}$ \\
\hline Rennin & $\begin{array}{c}41.63 \\
\pm 1.029\end{array}$ & $\begin{array}{c}103.0 \\
\pm 12.55^{*}\end{array}$ & $\begin{array}{c}111.6 \\
\pm 7.359^{*}\end{array}$ & $\begin{array}{c}176.8 \\
\pm 27.21^{*}\end{array}$ & $\begin{array}{c}79.87 \\
\pm 18.85^{* \neq}\end{array}$ & $\begin{array}{c}80.22 \\
\pm 11.20^{* \neq}\end{array}$ & $\begin{array}{c}74.55 \\
\pm 16.56^{* \neq}\end{array}$ \\
\hline IL6 & $\begin{array}{c}31.00 \\
\pm 0.438\end{array}$ & $\begin{array}{c}116.0 \\
\pm 13.27^{*}\end{array}$ & $\begin{array}{c}120.6 \\
\pm 6.822^{*}\end{array}$ & $\begin{array}{c}148.8 \\
\pm 20.64\end{array}$ & $\begin{array}{c}80.73 \\
\pm 8.077^{* \neq}\end{array}$ & $\begin{array}{c}69.68 \\
\pm 18.78^{* \neq}\end{array}$ & $\begin{array}{c}60.58 \\
\pm 2.838^{* \neq}\end{array}$ \\
\hline
\end{tabular}

Results are expressed as means $\pm S D(n=6)$. *significant difference from control group, $\neq$ significant difference from $(C P+I R R)$ treated group at $P<0.05$.

\begin{tabular}{|c|c|c|c|c|c|c|c|}
\hline \multirow[b]{3}{*}{ Parameter } & \multicolumn{7}{|c|}{ Experimental groups } \\
\hline & Group 1 & Group 2 & Group 3 & Group 4 & Group 5 & Group 6 & Group 7 \\
\hline & Control & CP & IRR & $\mathrm{CP}+\mathrm{IRR}$ & $\begin{array}{c}\mathrm{FO}+\mathrm{CP}+ \\
\text { IRR }\end{array}$ & $\begin{array}{l}\text { SeNPs + CP } \\
\quad+\text { IRR }\end{array}$ & $\begin{array}{c}\text { FO+ } \\
\text { SeNPs+ } \\
\text { CP+ IRR }\end{array}$ \\
\hline XO & $\begin{array}{c}0.186 \pm \\
0.037\end{array}$ & $\begin{array}{c}0.410 \pm \\
0.144^{*}\end{array}$ & $\begin{array}{l}0.452 \pm \\
0.041^{*}\end{array}$ & $\begin{array}{l}0.408 \pm \\
0.141^{*}\end{array}$ & $\begin{array}{c}0.356 \\
\pm 0.138^{\star} \\
\end{array}$ & $\begin{array}{c}0.382 \\
\pm 0.077^{\star}\end{array}$ & $\begin{array}{c}0.2940 \pm \\
0.088\end{array}$ \\
\hline Angiotensinogen & $\begin{array}{c}1.040 \pm \\
0.036\end{array}$ & $\begin{array}{c}5.135 \pm \\
0.989^{*}\end{array}$ & $\begin{array}{c}3.160 \pm \\
0.695^{*}\end{array}$ & $\begin{array}{c}6.717 \pm \\
1.235^{*}\end{array}$ & $\begin{array}{c}1.965 \\
\pm 0.279^{\neq}\end{array}$ & $\begin{array}{c}2.920 \pm \\
0.120^{*}\end{array}$ & $\begin{array}{c}1.577 \\
\pm 0.374^{\neq}\end{array}$ \\
\hline
\end{tabular}

Results are expressed as means $\pm S D(n=6)$. *significant difference from control group, $\neq$ significant difference from $(C P+I R R)$ treated group at $P<0.05$.

in the inflammatory process and increases vascular permeability through the release of prostaglandins and vascular endothelial cell growth factor (VECG) that initiates the inflammatory process. ${ }^{33}$ AngII induce the expression and transcription of the cytokines family via activation of NF- $x \mathrm{~B}$-dependent pathway and IL- 6 transcription in rats leading to organ damage, ${ }^{34}$ which is in agreement with our present conclusion. Taken together, these data suggest that compounds blocks AngII receptor and inhibits renin can slow inflammatory processes and disease progression.

$\mathrm{Nrf2}$ is an important regulator in the anti-oxidative reaction of the cells, it interacts with the antioxidant response element (ARE), and plays a wide range of Cytoprotective roles in anti-oxidative, anti-apoptotic, and anti-inflammatory responses. ${ }^{35}$ Under resting conditions, Nrf2 is restored in the cytoplasm by Keap1, an adaptor. ${ }^{36}$ Under oxidative stress, Nrf2 is released from Keap1 and translocate to the nucleus where it up regulates ARE-dependent cytoprotective genes such as glutathione transferase, GPx and catalase. ${ }^{37}$

Our result further indicated that the rats orally treated with FO and SeNPs before CP and $\gamma$-irradiation significantly ameliorated the double unfavorable effect of using CP and $\gamma$-irradiation. This is evident by the increase in the level of antioxidant enzymes PON-1, 

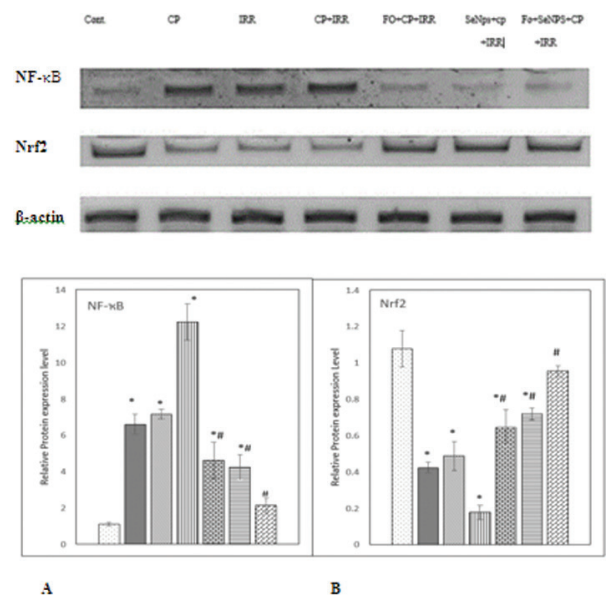

Figure 1: Effect of FO and/ or SeNPs on NF-kB (A) and Nrf2

(B) protein expression in cisplatin irradiated rats. Results was quantified by densitometry and corrected by reference to $\beta$-actin. Results are expressed as means $\pm \operatorname{SD}(n=6)$. *significant difference from control group,

" significant difference from (CP+IRR) treated group at $\mathrm{P}<0.05$.

GPx in liver and the decrease in the activity of renin as well as the level of IL6 in serum. Such treatment caused activation of liver $\mathrm{Nrf2}$ protein expression along with an inhibition in the expression of $\mathrm{XO}$, angiotensinogen and $\mathrm{NF}-x \mathrm{~B}$ expression in liver tissue.

Literature survey revealed that EPA and DHA fatty acids have antioxidant properties and play a vital role in free radical metabolism. ${ }^{38}$ These effects occur partly via activation of Peroxisome proliferator-activated receptors (PPARs) by $\mathrm{n}-3$ polyunsaturated fatty acids in fish oil. ${ }^{39}$ Previous study reported that PPAR $\gamma$ is an important factor in the regulation of PON1 expression, and in neutralizing oxidative stress. PPAR $\gamma$-mediated activation of Nrf2 signaling, results in Nrf2-dependent inhibition of pro-inflammatory pathways. ${ }^{40} \mathrm{In}$ addition, $\operatorname{PPAR} \gamma$ and Nrf2 are connected by a positive feedback loop that confirms the expression of both transcription factors and antioxidant. All at once, the two genes utilize a powerful anti-inflammatory action preventing the $\mathrm{NF}-x \mathrm{~B}$ pathway. ${ }^{41}$ On the other hand, previous studies revealed that selenium plays important roles in the enhancement of the antioxidant defense system, ${ }^{42}$ increased GPx activity, ${ }^{43}$ scavenge the free radicals and $\mathrm{ROS}^{44}$ and down regulate the NF- $x \mathrm{~B}$ pathway ${ }^{45}$ Consistent with previous study, SeNPs plays important roles in the enhancement of the antioxidant defense system whereas, the administration of SeNPs caused a marked improvement in hepatic antioxidant activities, which is due to its function in the active site of many antioxidant enzymes; like GPx. ${ }^{46}$ selenium compounds or its metabolites may directly activate the Nrf2 pathway by modifying critical thiols in Keap $1 .{ }^{47} \mathrm{Nrf} 2$ activators might be a successful strategy to control disease, which is associated with oxidative injuries. ${ }^{48}$ Consequently, in the current study the tested combination of both FO and SeNPs may reveal the totality of efficiency of either compound alone; as they act by more than one mechanism. Combined treatment of FO and SeNPs may counteract the liver toxicity at the biochemical and molecular levels by participating in the repair and regeneration of injured membrane structures resulted from intensive exposure to oxidative stress.

\section{CONCLUSION}

The present study indicates that administration of FO together with SeNPs could ameliorate the hepatotoxic effect induced by $\mathrm{CP}$ and radiation exposure. The mechanisms underlying these promising effects could be through increasing Nrf2 expression which ameliorates antioxidant status, increasing GPX, PON1, in addition to diminishing the pro inflammatory markers IL6, therefore decreasing the expression of NF- $x \mathrm{~B}$.

\section{ACKNOWLEDGMENT}

The authors are appreciated to Dr. to Ahmed Ibrahim El-Batal, professor of Applied Microbiology (NCRRT) for his cooperation in preparing SeNPs.

\section{CONFLICT OF INTEREST}

The authors declared there is no conflict of interest.

\section{REFERENCES}

1. Li L, Story M, Legerski R. Cellular responses to ionizing radiation damage. Int J Radiat Oncol Biol Phys. 2001;(49):1157-62. http://dx.doi.org/10.1016/ S0360-3016(00)01524-8

2. Hassan I, Chibber S, Naseem I. Ameliorative effect of riboflavin on the cisplatin induced nephrotoxicity and hepatotoxicity under photoillumination. Food Chem Toxicol. 2010;48(8):2052-8. http://dx.doi.org/10.1016/j. fct.2010.05.004; PMid:20457210

3. Gao P, GaoY, Lang H. Effect of NF-KBinhibitor PDTc on VEGF and endostatin expression of mice with lewis lung cancer. APJTM. 2015; 220-24.

4. LiN, Karin M. lonizing radiation and shortwavelength UV activate NF-KBthrough two distinct mechanisms. Proc Natl Acad Sci USA. 1998;95(22):13012-7. http://dx.doi.org/10.1073/pnas.95.22.13012; PMid:9789032 PMCid:PMC23690

5. Piret B, Schoonbroodt S, Piette J. The ATM protein is required for sustained activation of NF-KB following DNA damage. Oncogene. 1999;18(13):2261-71. http://dx.doi.org/10.1038/sj.onc.1202541; PMid:10327072

6. Li W, Kong AN. Molecular mechanisms of Nrf2-mediated antioxidant response. Mol Carcinog. 2009;48(2):91-104. http://dx.doi.org/10.1002/ mc.20465 ; PMid:18618599 PMCid:PMC2631094

7. Nair S, Doh ST, Chan JY, Kong AN, Cai L. Regulatory potential for concerted modulation of Nrf2- and Nfkb1-mediated gene expression in inflammation and carcinogenesis. $\mathrm{Br} \mathrm{J}$ Cancer. 2008;99(12):2070-82. http://dx.doi. org/10.1038/sj.bjc.6604703 ; PMid:19050705 PMCid:PMC2607222

8. Kim BM, Hong Y, Lee S, Liu P, Lim JH, Lee YH. Therapeutic Implications for Overcoming Radiation Resistance in Cancer Therapy. Int $\mathrm{J}$ Mol 
Sci. 2015;16(11):26880-913. http://dx.doi.org/10.3390/ijms161125991; PMid:26569225 PMCid:PMC4661850

9. Ma Y, Chapman J, Levine M, Polireddy K, Drisko J, Chen Q. High-dose parenteral ascorbate enhanced chemo-senstivity of ovarian cancer and reduced toxicity of chemotherapy. Sci Transl Med. 2014;6(222):222ra18 http://dx.doi.org/10.1126/scitranslmed.3007154

10. Naqshbandi A, Khan MW, Rizwan S, Yusufi ANK, Khan F. Studies on the protective effect of fish oil against cisplatin induced hepatotoxicity. Biol Med. 2011;3(2):86-97.

11. Kang JX, Weylandt KH. Modulation of inflammatory cytokines by omega 3 fatty acids. Subcell Biochem. 2008;(49):133-43. http://dx.doi.org/10.1007/978-14020-8831-5_5 ; PMid: 18751910

12. Wall R, Ross RP, Fitzgerald GF, Stanton $C$. Fatty acids from fish: the antiinflammatory potential of long chain omega-3 fatty acids. Nutr Rev. 2010; 68(5):280-9. http://dx.doi.org/10.1111/j.1753-4887.2010.00287.x; PMid:20500789

13. Chen YCKS, Andrea M. Mastro AM. Is Selenium a Potential Treatment for Cancer Metastasis?. Nutrients. 2013;5(4):1149-68. http://dx.doi.org/10.3390/ nu5041149 PMid:23567478 PMCid:PMC3705340

14. Hassanin KMA, Abd El-Kawi SH, Hashem KS. The prospective protective effect of selenium nanoparticles against chromium-induced oxidative and cellular damage in rat thyroid. Int J Nanomed. 2013;(8):1713-20.

15. Zhang J, Wang $\mathrm{H}$, Yan $\mathrm{X}$, Zhang L. Comparison of short-term toxicity between Nano-Se and selenite in mice. Life Sci. 2005;76(10):1099-109. http://dx.doi. org/10.1016/j.lff.2004.08.015; PMid:15620574

16. Zhang J, Zhang SY, Xu JJ, Chen HY. A new method for the synthesis of selenium nanoparticles and the application to construction of $\mathrm{H} 2 \mathrm{O} 2$ biosensor. Chin Chem Lett. 2004;15(11):1345-8.

17. Wang $\mathrm{H}$, Zhang J, $\mathrm{Yu} \mathrm{H}$. Elemental selenium at nano size possesses lower toxicity without compromising the fundamental effect on selenoenzymes: comparison with selenomethionine in mice. Free Radic74 Biol Med. 2007;42(10):1524-33. http://dx.doi.org/10.1016/j.freeradbiomed.2007.02.013 PMid: 17448899

18. Fahmy HA, Gharib OA. Effect of Low Radiation Dose on Cisplatin Induced Hepato- Testicular Damage in Male Rats. Brit J Pharmace Res. 2014;4(9):1053-66. http://dx.doi.org/10.9734/BJPR/2014/8980

19. Denny KM, Muralidhara M. Fish oil prophylaxis attenuate rotenone- induced oxidative impairments and mitochondria dysfunction in rat brain. Food Chem Toxico. 2012;50(5):1529-37. http://dx.doi.org/10.1016/j.fct.2012.01.020; PMid:22289576

20. El- Batal A, Thabet NM, Osman A, Abdel Rahman B, Abdel Ghaffar B, Azab K.Sh. Amelioration of oxidative damage induced in gamma irradiated rats by nanoselenium and lovastatin mixture. World Appl. Sci. J. 2012; 19 (7): 962- 71.

21. Rodrigo L, Gil F, Hernandez AF, Marina A, Vazquez J, Pla A. Purification and characterization of paraoxon hydrolase from rat liver. Biochem J. 1997;321(3):595-601. http://dx.doi.org/10.1042/bj3210595 ; PMid:9032442 PMCid:PMC1218111

22. Rotruck JT, Pop AL, Ganther HE, Swanson AB, Hafeman DG, Hoekstra WG. Selenium biochemical role as a component of glutathione peroxidase. Science 1. 1973;179(4073):588-90. http://dx.doi.org/10.1126/science.179.4073.588

23. Livak KJ, Schmittgen TD. Analysis of Relative Gene Expression Data Using Real-Time Quantitative PCR and the 22DDCT. Methods. 2001;25(4):402-8. http://dx.doi.org/10.1006/meth.2001.1262; PMid:11846609

24. Yildirimr S, Karadeniz A, Karakoc A, Yildirim A, Kalkan Y, Simsek N. Effects of royal jelly on liver paraoxonase activity in rats treated with cisplatin. Turk $J$ Med Sci. 2012;42(3):367-75.

25. Mansour HH, Hafez HF, Fahmy NM. Silymarin modulates Cisplatininduced oxidative stress and hepatotoxicity in rats. J Biochem Mol Biol. 2006;39(6):656-61. http://dx.doi.org/10.5483/BMBRep.2006.39.6.656; PMid:17129399

26. Mc Manaman JL, Bain DL. Structural and conformational analysis of the oxidase to dehydrogenase conversion of xanthine oxidoreductase. J Biol Chem. 2002;277(24):21261-8. http://dx.doi.org/10.1074/jbc.M200828200; PMid:11914370

27. Asıłhan A, Recep Ç, Imge B, Erdinç ED, Bülent K, Özden ÇH. Cisplatin causes oxidation in rat liver tissues: Possible protective effects of antioxidant food supplementation. Turk J Med Sci. 2008;38(2):117-20.
28. Xiao C, Jia Li, Zhuo L. Nuclear factor-kB as a hormonal intracellular signaling molecule: focus on angiotensin II-induced cardiovascular and renal injury. Curr Opin Nephrol Hypertens. 2008;17(1):37-43. http://dx.doi.org/10.1097/ MNH.0b013e3282f2903c; PMid:18090668 PMCid:PMC2278240

29. Basu S, Rosenzweig K, Youmell M, Price B. The DNAdependent protein kinase participates in the activation of NF-kB following DNA damage. Biochem Biophys Res Commun. 1998;247(1):79-83. http://dx.doi. org/10.1006/bbrc.1998.8741 ; PMid:9636658

30. Rotman G, Shiloh Y. ATM: a mediator of multiple responses to genotoxic stress. Oncogen. 1999;18(45):6135-44. http://dx.doi.org/10.1038/ sj.onc.1203124; PMid:10557105

31. Guo L, Richardson KS, Tucker LM, Doll MA, Hein DW, Arteel GE. Role of the renin-angiotensin system in hepatic ischemia reperfusion injury in rats. Hepatology. 2004;40(3):583-9. http://dx.doi.org/10.1002/hep.20369; PMid:15349896

32. Lai HS, Wen HSI, Lin WH, Shuo-Lun LSL, Hao-Yu LHY, Wen-Ming HWM. Interleukin-6 Mediates Angiotensinogen Gene Expression during Liver Regeneration. Plos one. 2013;8(7):e67868. doi:10.1371/journal. pone.0067868. http://dx.doi.org/10.1371/journal.pone. 0067868

33. Suzuki Y, Ruiz-Ortega M, Lorenzo O. Inflammation and angiotensin II. Int J Biochem Cell Biol. 2003;35(6):881-900. ; http://dx.doi.org/10.1016/S13572725(02)00271-6

34. Han Y, Runge MS, Brasier AR. Angiotensin II induces interleukin-6 transcription in vascular smooth muscle cells through pleiotropic activation of nuclear factor-kappa B transcription factors. Circ Res. 1999;2;84(6):695-703.

35. Li N, Nel AE. Role of the Nrf2-mediated signaling pathway as a negative regulator of inflammation: implications for the impact of particulate pollutants on asthma. Antioxid Redox Signal. 2006;8(1-2):88-98. http://dx.doi. org/10.1089/ars.2006.8.88; PMid:16487041

36. Kobayashi M, Yamamoto M. Molecular mechanisms activating the Nrf2-1 pathway of antioxidant gene regulation. Antioxid Redox Signal. 2005;(7):385-94.

37. Kang MI, Kobayashi A, Wakabayashi N, Kim SG, Yamamoto M. Scaffolding of Keap1 to the actin cytoskeleton controls the function of Nrf2 as key regulator of cytoprotective phase 2 genes. Proc Natl Acad Sci U S A. 2004;101(7):2046-51. http://dx.doi.org/10.1073/pnas.0308347100; PMid:14764898 PMCid:PMC357049

38. Merendino N, Costantini L, Manzi L, Molinari R, D'Eliseo D, Velotti F. Dietary $\omega-3$ Polyunsaturated Fatty Acid DHA: A Potential Adjuvant in the Treatment of Cancer. Bio Med Res Int. 2013; 310186. http://dx.doi.org/10.1155/310186.

39. Wakutsu M, Tsunoda N, Shiba S, Muraki E, Kasono K. Peroxisome proliferator-activated receptors (PPARs)-independent functions of fish oil on glucose and lipid metabolism in diet-induced obese mice. Lipids Health Dis. 2010;9(1):1. doi: 10.1186/1476-511X-9-101. http://dx.doi.org/10.1186/1476511X-9-101

40. Camps J, Heredia A, CarlosAlonso-Villaverde A, GerardAragon'es, Beltr'anDeb $R^{\prime}$ on, Rodr'iguez-Gallego E, Joven J. PPARs in Regulation of Paraoxonases: Control of Oxidative Stress and Inflammation Pathways. PPAR. 2012; doi:10.1155/2012/616371. http://dx.doi.org/10.1155/2012/616371

41. Polvani S, Tarocchi M, Andrea Galli A. PPAR and Oxidative Stress: Con ( $\beta$ ) Catenating NRF2 and FOXO. PPAR 2012; (10) http://dx.doi. org/10.1155/641087.

42. Hasanuzzaman M, Fujita M. Selenium pretreatment up regulates the antioxidant defense and methylglyoxal detoxification system and confers enhanced tolerance to drought stress in rapeseed seedlings. Biol Trace Elem Res. 2011;143(3):1758-6. http://dx.doi.org/10.1007/s12011-011-8958-4 http://dx.doi.org/10.1007/s12011-011-8998-9 ; PMid:21347652

43. Imamura S, Yabu T, Ishihara K, Yamashita $\mathrm{Y}$, Yamashita M. Ionizing radiation resistance mediated by the novel selenium-containing antioxidant selenoneine. The FASEB. 2013;27(1):757-63.

44. Al-Othman AM, Al-Numair S, El-Desoky KG, Yusuf K, Al Othman ZA, AboulSoud MA, et al. Protection of $\alpha$-tocopherol and selenium against acute effects of Malathion on liver and kidney of rats. AJPP. 2011;5(10):1263-71. http://dx.doi.org/10.5897/ajpp11.226

45. KimY, Kim DC, Cho ES, Ko So, Kwon WY, Suh CJ, Shin HK. Antioxidant and anti-inflammatory effects of selenium in oral buccal mucosa and small intestinal mucosa during intestinal ischemia-reperfusion injury. Journal of 
Inflammation. 2014; (11):36. http://dx.doi.org/10.1186/s12950-014-0036-1; PMid:25383045 PMCid:PMC4223162

46. Flora SJ, Kannan JM, BP, Jaiswal DK. Combined administration of oxalic acid, succimer and its analogue for the reversal of gallium arsenide induced oxidative stress in rats. Arch Toxicol. 2002;76(5-6):269-76. http://dx.doi. org/10.1007/s00204-002-0347-5 ; PMid:12107644
47. Müller M, Banning A, Brigelius-Flohé R, Kipp A. Nrf2 target genes are induced under marginal selenium-deficiency Genes Nutr. 2010;5(4):297-307. http://dx.doi.org/10.1007/s12263-010-0168-8; PMid:21189866 PMCid:PMC 2989369

48. Jung K, Kwak M. The Nrf2 System as a Potential Target for the Development of Indirect Antioxidants Molecules. 2010;15:7266-91.

\section{PICTORIAL ABSTRACT}

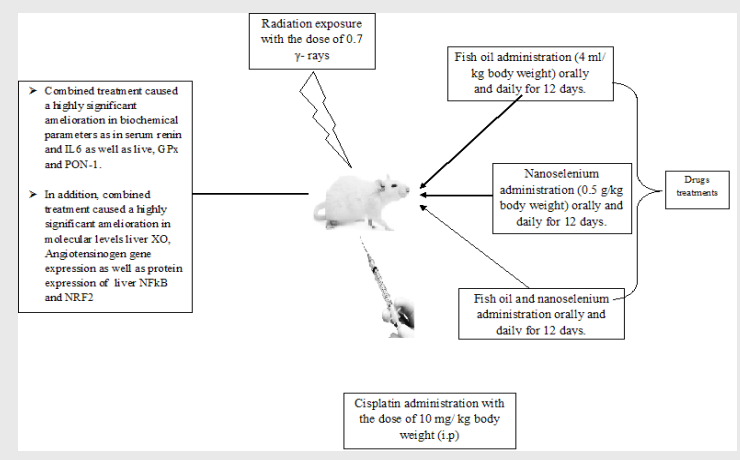

\section{About Authors}

Hanan A Fahmy: Lecturer of Biochemistry, Drug Radiation Research Department, National Center of Radiation Research and Technology, Atomic Energy Authority. Graduated from faculty of pharmacy Cairo university.

Afrag Sh Abd El- Azim: Lecturer at Radiation Biology Department, National Center of Radiation Research and Technology, Atomic Energy Authority.

Ola A Gharib: Assistant Professor of Biochemistry, Drug Radiation Research Department, National Center of Radiation Research and Technology, Atomic Energy Authority. Graduated from faculty of science Ain Shams university. 